\author{
Anetta Bogusława STRAWIŃSKA \\ Uniwersytet w Białymstoku \\ a.strawinska@uwb.edu.pl \\ http://orcid.org/0000-0001-8401-3068
}

\title{
GLOKALIZACJA. PRÓBA KULTUROWEJ DEFINICJI ZJAWISKA
}

\begin{abstract}
(...) nie żyjemy w dobie globalizacji, jak się nam przez długi czas wydawało, lecz w czasach glokalizacji cechującej się ambiwalencją i niejasnością celów oraz natury tego procesu, jak również, a może nawet przede wszystkim, jego implikacji ekonomicznych, społecznych, kulturowych i politycznych. Owa ambiwalencja i niejasność, a co za tym idzie swoiste rozmycie glokalizacji, wynika z tego, że współczesna gospodarka i kultura oraz współczesne społeczeństwo są coraz bardziej homogeniczne i jednolite w skali świata, a zarazem coraz bardziej heterogeniczne i zróżnicowane w skali lokalnej ${ }^{1}$.
\end{abstract}

Zjawisko określane mianem glokalizacji należy do najnowszych procesów z zakresu współczesnej przedsiębiorczości. Z wymiaru ekonomicznego glokalizacja zostaje przeniesiona na grunt nauk społecznych. Szczegółowy opis przywoływanego mechanizmu przynoszą głównie prace dotyczące systemu gospodarczego oraz szeroko rozumianego handlu. W językoznawstwie do tej pory glokalizacja stanowi obszar badawczy - według mnie - nie do końca spenetrowany. Artykuł jest próbą usystematyzowania rozumienia zjawiska wypracowanego przez naukowców reprezentujących poza językoznawstwem takie dyscypliny, jak: ekonomia, socjologia, politologia czy antropologia kultury. Tekst ten traktować należy zatem jako przyczynek do dalszych badań o charakterze cros-, trans- i interdyscyplinarnym ${ }^{2}$. Uwzględnienie dorobku różnych

\footnotetext{
1 Kuciński 2011: 22; http://mazowsze.hist.pl/29/Rocznik_Zyrardowski/891/2011/34 196/ [dostęp: 27.04.2020].

2 Taką metodologiczną rekomendację formułuje w latach 90. XX wieku Roland Robert-
} 
dyscyplin $\mathrm{w}$ procesie formułowania definicji kwantyfikowanego terminem glokalizacja zjawiska jest $\mathrm{w}$ moim przekonaniu niezbędne. Pojęcie glokalizacja określające przywoływany proces ma bowiem nacechowanie specjalne. Reprezentuje ono najnowsze słownictwo fachowe docierające do polszczyzny wraz z falą zapożyczeń związanych z procesem globalizacji ${ }^{3}$. Tendencje globalizacyjne polegają głównie na „zwiększeniu obrotów handlu międzynarodowego, nasileniu przepływu kapitału, ludzi i technologii oraz zacieraniu różnic kulturowych" 4 a pod względem językowym doprowadzają do zwiększania liczby nowych jednostek oraz nadawania nowych znaczeń wyrazowych, a także przejmowania przez polszczyznę potoczną jako centrum systemu stylowego współczesnego języka polskiego (Bartmiński 2001: 116-117) nowego słownictwa zawodowego (Smółkowa 2001: 397-398) oraz internacjonalizmów, głównie z zakresu marketingu i public relations (zob.: Dąbrowska 2000, Kuć 2011). Jednym z produktów finalnych zmian cywilizacyjnych o ogólnoświatowym zasięgu niewątpliwie jest wyraz glokalizacja: ang. glocalisation, niem. Glokalisierung, ros. глокализация, wł. glocalizzazione, hiszp. glocalización. Tradycyjne rodzime opracowania o charakterze słownikowym z końca XX i początku XXI wieku omawianego leksemu nie notują ${ }^{5}$. Słowo glokalizacja rejestrują natomiast źródła internetowe. Przywoływany wyraz poświadcza elektroniczny Słownik języka polskiego PWN ${ }^{6}$ oraz Narodowy Korpus Języka Polskiego 2008-20107 w wersji online. Odnotowują go również ustawicznie

son, gdyż glokalizacja ma nie tyle socjologiczny, kulturowy, językowy i antropologiczny wymiar, ile ekonomiczny, ekologiczny oraz polityczny. Zob. http://www.scienzesociali. aliun.it/st/docenti/robertson.shtml [dostęp: 27.04.2020].

3 Proces globalizacji, najogólniej rzecz ujmując, polega „w skali świata na coraz szerszej wymianie handlowej, nasileniu przepływu kapitału, ludzi, technologii i informacji między państwami i w efekcie na zacieraniu różnic kulturowych", za: Andrzej Markowski i Ryszard Pawelec Wielki stownik wyrazów obcych i trudnych, Warszawa 2001, s. 274 (dalej: WSWOiT). Szczegółowej analizy zjawiska globalizacji i jej wpływu na zachowania językowe współczesnych Polaków dokonuję w tekstach z 2018 (2018a: 197-215 oraz 2018b: 145-165).

4 http://sjp.pwn.pl/sjp/globalizacja;2559335 [dostęp: 23.06.2016].

5 Przywoływane słowo nie zostało odnotowane w Słowniku języka polskiego, pod red. Mieczysława Szymczaka, Warszawa 1992. Nie znajdziemy go również w Słowniku wspótczesnego języka polskiego, pod red. Bogusława Dunaja, Warszawa 2000 oraz Uniwersalnym słownik języka polskiego, pod red. Stanisława Dubisza, Warszawa 2003. Także WSWOiT wyrazu glokalizacja nie zaświadcza.

6 https://sjp.pwn.pl/szukaj/glokalizacja.html [dostęp: 30.01.2020].

7 Narodowy Korpus Języka Polskiego jest wspólną inicjatywą Instytutu Podstaw Informatyki PAN (koordynator), Instytutu Języka Polskiego PAN, Wydawnictwa Naukowego 
uaktualniane crowdsourcingowe 8 źródła internetowe o charakterze encyklopedycznym ${ }^{9}$ oraz tworzone w oparciu o tę najnowocześniejszą metodę pozyskiwania materiału językowego takie portale wiedzy o charakterze leksykograficznym, jak: Obserwatorium Językowe Uniwersytetu Warszawskiego ${ }^{10}$ oraz Obserwatorium żywej kultury ${ }^{11}$. Najaktualniejszy korpus współczesnej polszczyzny, tj. wyszukiwarka korpusowa Monco PL ${ }^{12} \mathrm{w}$ kwietniu 2020 roku dla leksemu glokalizacja wskazuje tylko 18 wyników ${ }^{13}$. Źródła,

PWN oraz Zakładu Językoznawstwa Komputerowego i Korpusowego Uniwersytetu Łódzkiego. To nie tyle zbiór tekstów ilustrujących typowe użycia słów i konstrukcji językowych, ile dodatkowo źródło innych informacji o znaczeniu i funkcji odnotowanych jednostek. Lista źródeł Korpusu... poza klasyką literatury polskiej zawiera także prasę codzienną i specjalistyczną, nagrania rozmów, teksty ulotne i internetowe (dalej: NKJP), http://nkjp.pl/ [dostęp: 30.01.2020].

8 Crowdsourcing (ang. crowd 'tłum', sourcing 'zaopatrzenie, źródło zaopatrzenia') jest określany mianem „wolontariatu XXI wieku” lub "mądrością tłumu” [www.karieraw finansach.pl; dostęp: 30.01.2020]. Do realizacji badań angażuje się szeroką grupę ludzi; internautów reprezentujących różne warstwy społeczne; często niespecjalistów. W działaniach crowdsourcingowych każdy głos „zindywidualizowanego tłumu” jest ważny (Wierżyński 2015).

9 Wikipedia, hasło: glokalizacja, https://pl.wikipedia.org/wiki/Glokalizacja [dostęp: 07.02. 2019].

10 Obserwatorium Językowe Uniwersytetu Warszawskiego. Najnowsze słownictwo polskie, hasło: glokalizacja, http://nowewyrazy.uw.edu.pl/haslo/glokalizacja.html [dostęp: 07.02.2019], dalej: OJUW. Członkami redakcji naukowej obserwatorium są: prof. Mirosław Bańko, Maciej Czeszewski oraz Jan Burzyński. Ideą pomysłodawców słownika OJUW jest rejestrowanie nowych wyrazów, które zasilają współczesną polszczyznę prawie codziennie „,i które przyjmują się w języku niemal na naszych oczach”, http://naukawpolsce.pap.pl/ aktualnosci / news \%2C401876\%2Cobserwatorium-jezykowe-uw-zbiera-od-internautownowe-slowa.html [dostęp: 30.01.2020].

11 Obserwatorium żywej kultury. Sieć badawcza (dalej: OŻK) poświadcza analizowany leksem w Słowniku inspiracji z odwołaniem do rozprawy pt. Nowoczesność bez granic. Kulturowe wymiary globalizacji [Appadurai 2005: 16]. Obserwatorium żywej kultury. Sieć badawcza powstało z inspiracji Przemysława Zielińskiego i Joanny Szwajcowskiej. Jest to Portal Wiedzy - współtworzony przez Sieć Badawczą składającą się ze współpracujących ze sobą Zespołów Merytorycznych zwanych Węzłami (gdy Zespoły mają oparcie instytucjonalne) oraz Pętelkami (gdy tworzą je pojedyncze osoby) - o kulturze współczesnej, "głównie polskiej, o jej przeszłości, kontekstach i związkach z kulturą europejską i światową", http://ozkultura.pl/wpis/649/9 [dostęp: 30.01.2020].

12 Korpus „pomaga znaleźć przykłady użycia wyrazów, fraz oraz wzorców leksykalno-gramatycznych w autentycznych próbkach współczesnej polszczyzny" [http://monco. frazeo.pl/, dostęp: 27.04.2020]. Indeks wyszukiwarki jest systematycznie uaktualniany. Obecnie zawiera ponad 5 miliardów segmentów słów. Ogląd danych językowych możliwy jest w ramach czterech modułów: konkordancje, podsumowanie, fasety (typy tekstów), pliki. Dodatkowo możliwy jest dostęp do opcji kolokacje. Poza tym dane językowe są wizualizowane i ujmowane statystycznie (por. Pałka, Kwaśnicka-Janowicz 2017: 158).

13 Dla porównania wyszukiwarka korpusowa PELCRA dla danych NKJP przytacza tylko jedno cytowanie, tj. dwa przykłady z jednego tekstu. Definicję przytaczam w przypisie 16. niniejszego artykułu. 
z których pochodzą konteksty występowania leksemu glokalizacja to: krytykapolityczna.pl, interia.pl, money.pl, innpoland.pl, niedziela.pl ${ }^{14}$. Jak wynika z danych korpusowych, największa częstotliwość występowania leksemu glokalizacja przypada na sierpień 2018 roku. Pierwsze wystąpienie słowa glokalizacja odnotowano w wyszukiwarce Monco PL w dniu 13.09.2014 roku. Ostatnie notowanie pochodzi z 21.03.2019 roku. Wyszukiwarka wskazuje 5 tekstów-komunikatów zawierających słowo glokalizacjia. Wyraz glokalizacja występuje w nich jako składnik tytułu, śródtytułu oraz jeden $\mathrm{z}$ elementów treści programowych warsztatów skierowanych do pedagogów ${ }^{15}$ :

Glokalizacja, blockchainy i anty-Food Waste. Nowa gospodarka oczami największych ekspertów (14.08.2018; innpoland.pl, money.pl);

Glokalizacja? Jak światowe koncerny rosną na regionalnych produktach (14.08.2018; money.pl);

Czy glokalizacja może być narzędziem rozwojowym w rękach - nie tylko lokalnych - przedsiębiorców? (14.08.2018; innpoland.pl);

Główne tematy poruszane przez edukację globalną: obywatelstwo globalne, globalne współzależności, glokalizacja, edukacja międzykulturowa, zmiany klimatyczne (13.09.2014, krytykapolityczna.pl);

W Krynicy: Glokalizacja - o korzyściach z godzenia sprzeczności (22.08.2018, interia.pl).

Jak wcześniej sygnalizowałam, wyraz glokalizacja należy do słownictwa profesjonalnego (Buttler 1973: 42, 1982: 27; Piekot 2008: 20) w rozprawach językoznawczych nazywanego także zawodowym (Klemensiewicz 1953: 38-43; Furdal 1973: 34-36; Skubalanka 1976: 261; Wilkoń 2003: 41-52; Pisarek 2006: 254), specjalistycznym (Lukszyn (red.) 2005: 48) czy też fachowym/wyspecjalizowanym (Urbańczyk 1956: 23-26). Za profesjolekty - przywołując ustalenia Aleksandra Wilkonia - uznaję „odmianki potoczne (w skład profesjolektu, zdaniem badacza, wchodzą słownictwo potoczne i słownictwo zawodowe/specjalne, z naciskiem na potoczność - dop. A.S.), realizujące się w fachowych rozmowach, dyskusjach,

14 Dane liczbowe znaleźć można na stronie http://monco.frazeo.pl/ [dostęp: 27.04.2020].

15 Celem warsztatów zorganizowanych przez Akademię Animatorów Zrównoważonego Rozwoju było „,kształtowanie kompetencji niezbędnych do (...) nauczania o globalnych problemach w taki sposób, by efektem była trwała zmiana postawy", https://krytykapoli tyczna.pl/kraj/miasto/akademia-animatorow-zrownowazonego-rozwoju [dostęp: 27.04. 2020]. 
naradach, w procesie wytwarzania, a więc w konkretnych sytuacjach i aktach mowy" (2000: 102). Leksem glokalizacja w pracach z zakresu ekonomii pojawia się $\mathrm{w}$ znaczeniu - najogólniej rzecz ujmując - procesu adaptacji globalnych strategii marketingowych do lokalnych warunków ${ }^{16}$. Termin glokalizacja po raz pierwszy został użyty w tekście opublikowanym na łamach Harvard Business Review dotyczącym popularnej w Japonii w latach 80. XX wieku strategii biznesowej. Słowo glokalizacja przywołano w kontekście procesu wprowadzania nowych praktyk sprzedaży (dochakuka) oraz dostosowywania globalnych produktów, ich reklamy i strategii marketingowych do lokalnych warunków, wymogów rynku oraz odbiorców (Guziejewska 2008: 5-6; Konopka 2015: 24). Istotę tego mechanizmu w sposób jednoznaczny oddaje maksyma autorstwa Patricka Geddesa, szkockiego projektanta i konserwatora przyrody: "Think globally, act locally" (tj. „myśl globalnie, działaj lokalnie” 1915) ${ }^{17}$. „Globalne myślenie staje się warunkiem efektywnego lokalnego działania, a sprzyjające trwałemu i zróżnicowanemu rozwojowi globalne działanie wymaga globalnego myślenia" (Miszczak 2013: 28-29). Glokalizacje z wymiaru ekonomicznego anektują nauki społeczne ${ }^{18}$. Transferu pojęcia

16 NKJP rejestruje następującą definicję terminu glokalizacja: „(...) to pojęcie, które opisuje między innymi odrodzenie tego co lokalne pod wpływem presji tego co globalne, ale też upowszechnianie lokalnych marek, towarów, wartości dzięki mediom globalizacji", http://www.nkjp.uni.lodz.pl/index_adv.jsp?query=glokalizacja\&Submit=\%C2\%A0\%C2\% $\mathrm{A} 0 \% \mathrm{C} 2 \% \mathrm{~A} 0 \% \mathrm{C} 2 \% \mathrm{~A} 0 \mathrm{SZUKAJ} \% \mathrm{C} 2 \% \mathrm{~A} 0 \% \mathrm{C} 2 \% \mathrm{~A} 0 \% \mathrm{C} 2 \% \mathrm{~A} 0 \% \mathrm{C} 2 \% \mathrm{~A} 0 \&$ span $=0 \&$ preserve_ order=true\&perpage=100\&sort=srodek\&second_sort=srodek\&groupBy=---\&groupByLim it $=1 \& m_{-}$style=---\&m_channel=---\&m_date_from $=$RRRR\&m_date_to=RRRR\&m_nkjpSubcor pus=balanced \&m_title_mono=\&m_title_mono_NOT=\&m_paragraphKWs_MUST=\&m_para graphKWs_MUST_NOT=\&m_text_title=\&dummystring=\%C4\%85\%C4\%84\%C4\%87\%C4\%

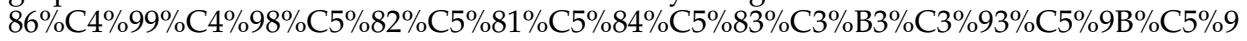
A\%C5\%BA\%C5\%B9\%C5\%BC\%C5\%BB [dostęp: 27.04.2020]. Niektórzy badacze glokalizację, czyli „rosnące znaczenie lokalnych społeczności i lokalnych gospodarek funkcjonujących $\mathrm{w}$ warunkach stwarzanych przez nabierające ogólnoświatowego charakteru procesy integracyjne oraz coraz większą rolę lokalnych warunków działania podmiotów gospodarczych realizujących swoje globalne strategie" (za: Kuciński 2011: 17) traktują jako rewers globalizacji; "alter ego podążające za nią niczym cień” (Kuciński 2011: 17, Słodowa-Hełpa 2017: 13).

17 Dzisiaj składniki tworzące maksymę uległy przetasowaniu tworząc nową jakość, tj. „myśl lokalnie, działaj globalnie” (Jewtuchowicz 2005: 44). Z glokalizacją, in. „zdecentralizowaną" globalizacją, "związane jest rosnące znaczenie lokalnych społeczności i gospodarek funkcjonujących w warunkach stwarzanych przez procesy integracyjne nabierające ogólnoświatowego charakteru oraz coraz większa rola lokalnych warunków działania podmiotów gospodarczych realizujących swoje globalne strategie" (Słodowa-Hełpa 2017: 13).

18 „W badaniach antropologicznych akcentuje się takie komponenty glokalizacji, które łączą w sobie dwie zależności: globalną produkcję idei, symboli, dóbr itp. z lokalnym charakterem kultur" (Słodowa-Hełpa 2017: 11). 
do antropologii społecznej dokonuje brytyjski socjolog i kulturoznawca Roland Robertson w 1995 roku. W artykule zatytułowanym The conceptual promise of glocalization: commonality and diversity R. Robertson akcentuje „nierozerwalność" wymiarów: globalnego i lokalnego ${ }^{19}$. Autor relacje między lokalnością i globalnością metaforycznie określa „nieustanną rozgrywką" doprowadzającą w rezultacie „do wzmacniania znaczenia lokalnego poziomu i podniesienia atrakcyjności poziomu globalnego poprzez oferowaną różnorodność i unikatowość przenikających się elementów" (por. Biernacka-Ligęza 2013: 164). Do koncepcji Robertsona odwołują się m.in. amerykański antropolog kulturowy indyjskiego pochodzenia Arjun Appadurai (The Production of Locality, 1995) oraz socjolog niemiecki Ulrich Beck (Risikogesellschaft. Auf dem Weg in eine andere Moderne 1986, Macht und Gegenmacht im globalen Zeitalter. Neue weltpolitische Ökonomie 2002) ${ }^{20}$. A. Appadurai współczesność kulturową opisuje za pomocą modelu globalnej dysjunkcji ${ }^{21}$ to znaczy rozszczepienia się różnych wymiarów aktywności ludzkiej (chociażby: polityki, gospodarki czy kultury) zbudowanego z pięciu metafor/krajobrazów takich, jak: etnokrajobraz, mediaobraz, technoobraz, finansoobraz oraz ideokrajobraz ${ }^{22}$. Owe krajobrazy autor porównuje do klocków, z których złożona jest zglobalizowana rzeczywistość ${ }^{23}$. U. Beck z kolei proponuje koncepcję współczesnego global-

19 Więcej: Jewtuchowicz 2005: 44. Zob. także: Veltz 1996: 122, Miszczak 2013: 20.

20 Przekład polski: U. Beck, Władza i przeciwwładza w epoce globalnej. Nowa ekonomia polityki światowej, tłum. J. Łoziński, Warszawa 2005.

21 Dysjunkcja jest przeciwieństwem koniunkcji, a więc wynikania, ścisłego związku przyczynowo-skutkowego między składowymi określonego procesu. Słowniki języka polskiego dysjunkcję definiują jako zdanie o znaczeniu 'albo... albo...' (prawdziwe tylko wtedy, gdy prawdziwe jest dokładnie jedno z jego zdań składowych). W logice natomiast dysjunkcja traktowana jest jako zdanie o znaczeniu 'co najwyżej jedno z...' (prawdziwe także wtedy, gdy oba zdania składowe są fałszywe). W opracowaniach z zakresu matematyki (np. The Penguin Dictionary of Mathematics 1989) dysjunkcję utożsamia się ze zwykłą alternatywą (niewykluczającą), https://sjp.pwn.pl/poradnia/haslo/dysjunkcja;12237.html [dostęp: 29.04.2020].

22 A. Appadurai etnokrajobraz rozumie jako nową wielokulturowość społeczeństw tworzoną przez turystów, imigrantów, uchodźców, gastarbeiterów wywierających w nieznanym wcześniej stopniu wpływ na politykę. Mediaobraz to z kolei zakres i przebieg dystrybucji informacji i ich nośniki oraz kreowane przez media obrazy świata. Technoobraz badacz odnosi do technologii, która przekracza nieprzenikalne dotąd granice, pociągając za sobą wysoko wykwalifikowaną siłę roboczą. Finansoobraz to globalny przepływ kapitału ujawniający niespójny charakter przepływów ludzi, technologii i finansów. Ideokrajobraz tworzą różne idee (często o charakterze politycznym) wokół których organizują się państwa narodowe.

23 To, zdaniem badacza, swoiste światy wyobrażone, w których ludzie poruszają się na 
nego społeczeństwa ryzyka (2004). Dwoista struktura ryzyka, w przeświadczeniu eksploratora, daje szansę samoaktywizacji nowoczesnych społeczeństw. Autor prognozuje swoisty „powrót” do politycznej geografii opartej na strukturze państw narodowych oraz konfliktów między nimi związanych zwłaszcza z bezrobociem, kryzysem ekologicznym, rewolucją płci czy regresem demograficznym ${ }^{24}$.

Strukturalnie leksem glokalizacja należy do kontaminacji leksykalnych ${ }^{25}$. „Pod względem budowy formalnej, kontaminacja jest rodzajem kompozycji polegającej na zespoleniu całych form wyrazowych lub ich części w jedną całość formalną, na zasadzie węzła lub węzłów kontaminacyjnych" (Grabias 1970: 120). Leksem glokalizacja powstał w wyniku połączenia wyrazów globalizacja oraz lokalizacja. Termin globalizacja jest stosowany na określenie zjawiska społecznego niezwykle trudnego do eksplicytnego wyjaśnienia. Wyznaczenie ram definicyjnych tej kategorii kulturowo-językowej komplikuje głównie jej wielowymiarowość (Strawińska 2018b: 146). Każda z licznych form, jakie przybiera omawiane zjawisko zawiera zarówno czynniki narodowe, jak i międzynarodowe, ogólnoświatowe (Strawińska 2018a: 197-199). Całokształt zjawisk charakteryzujących globalizację da się opisać czy rozpatrywać, wykorzystując zaproponowane przez Jana A. Scholtego komponenty takie, jak: internacjonalizacja, liberalizacja, uniwersalizm, westernizacja (modernizacja)/karnawalizacja i rozpad terytorium (por. Czainska 2010: 93). Lokalność może być rozumiana albo szeroko, jako element układu odniesienia czy strategii budowania tożsamości, albo też nieco węziej, jako obecność na określonym obszarze lub posiadanie charakteru stosownego do da-

co dzień. „Chociaż w znacznej mierze autonomiczne, są wzajemnie powiązane, napędzają się i przenikają" (zob. więcej: Pasmonik 2013: 121).

24 U. Beck tworzy nową koncepcję granic: „W pierwszej nowoczesności granice narodowe były wyraźnie wytyczone, w ponowoczesności granice zostały usunięte, natomiast w drugiej nowoczesności granice zostają podważone, zanika rozróżnienie między tym, co narodowe, a tym, co międzynarodowe, powstają nowe granice, nowe rozróżnienia (...). Obywatele sami otwierają granice. Koncepcja granic zakłada z jednej strony bezgraniczność, co gwarantować ma społeczeństwo światowe, w którym istnieją tożsamości narodowe, a z drugiej strony powstawanie nowych jakości, których granice wyznacza np. ekonomiczna współpraca czy zakres działania korporacji. Przekraczając dawne granice, budujemy nowe i dążymy do stabilizacji tych nowych struktur" (Kosmala 2005: 214).

25 Kontaminacja (łac. contaminatio 'zetknięcie'), czyli ‘skrzyżowanie/połączenie/zmieszanie dwóch (lub więcej) słów albo wyrażeń, zwykle zbliżonych semantycznie lub leksykalnie' (Buttler, Satkiewicz, Kurkowska 1986: 33, 258, 293; Otrębski 1948: 1; Grabias 1970: 117-118). 
nego miejsca. Lokalność może być też utożsamiana z odmiennym pod względem znaczenia lokalizmem; odpowiednikiem zamknięcia się jednostki lub grupy w wąskiej i ograniczonej przestrzeni lokalnej oraz nieufności wobec grup spoza lokalnego terytorium (Majer 2011: 28). Ideologia lokalizmu wyrasta między innymi z uznania więzi i solidarności społecznej za wartości o dużym znaczeniu oraz krytyki centralizmu państwowego. Lokalizm podkreśla „zasadniczą rolę stowarzyszeniowych form organizacji społeczeństwa oraz znaczenie władz lokalnych, które mogą być formą realizacji zasad samorządności" (Podedworna 1999: 113). Glokalizacja, według klasyfikacji Stanisława Grabiasa, jest kontaminacją wielowęzłową o uszczuplonej fonologicznie formie komponentu pierwszego i pełnej formie drugiego (1970: 125). Natomiast stosując kryterium relacji/stosunku znaczenia całego tworu kontaminacyjnego do znaczeń jego komponentów glokalizacja należy do kontaminacji będących ,jako twór semantyczny wypadkową znaczeń obydwu komponentów. Twory te, podobnie jak złożenia i zestawienia, stanowią zespolenie dwu składników na zasadzie szeregu (koordynacja)" (1970: 127). Glokalizacja to 'współwystępowanie sprzecznych tendencji, tj.: perspektywy globalizacyjnej i komunikacji regionalnej, lokalnej, środowiskowej i grupowej'26. Szczegółowego opisu mechanizmów ścierania się/iskrzenia/tarcia pomiędzy wymiarem globalnym a lokalnym dokonuje amerykański politolog oraz dziennikarz Thomas Lauren Friedman (2001). Posiłkując się dwoma kulturowo ustabilizowanymi symbolami, jakimi są Lexus ${ }^{27}$ i drzewo oliwne ${ }^{28}$ antropolog udowadnia, że sukces cywilizacyjny można osiągnąć poprzez zachowanie równowagi między tym co ponadnarodowe a tym, co światowym nie jest. Globalność - według T.L. Friedmana - wbrew pozorom, nie wyklucza lokalności ${ }^{29}$. Paradoksalnie owa lokalność staje się funda-

\footnotetext{
26 OŻK; https://sjp.pwn.pl/slowniki/umiejscowiony.html [dostęp: 27.04.2020].

27 Lexsus, jeden $\mathrm{z}$ najdroższych i najbardziej nowoczesnych samochodów osobowych świata, symbolizuje procesy globalizacyjne gospodarki oraz kultury światowej.

28 Drzewo oliwne stanowi odzwierciedlenie świata tradycyjnych wartości, utożsamianego przede wszystkim $\mathrm{z}$ wymiarem lokalnym.

29 Konkluzja T.L. Friedmana brzmi: „Każde społeczeństwo, które chce dziś osiągnąć sukces gospodarczy, musi bez przerwy budować jak najlepsze lexusy i ruszać nimi w świat. Niech nikt jednak nie ma złudzeń, że samo uczestnictwo w globalnej gospodarce pozwoli zbudować zdrowe społeczeństwo (...). Przetrwanie globalizacji jako systemu będzie po części zależało od tego, na ile będziemy potrafili utrzymać tę równowagę. Kraj bez zdrowych drzew oliwnych nigdy nie będzie miał wystarczającego poczucia zakorzenienia lub bezpieczeństwa, by w pełni się otworzyć na świat i wyjść do niego. Lecz kraj, który
} 
mentem, podwaliną, rdzeniem procesu umiędzynarodowienia ${ }^{30}$. Zgromadzone za pomocą wyszukiwarki Monco PL konteksty tezę tę bezsprzecznie potwierdzają, np.:

Umiejętność harmonijnego połączenia pierwiastka globalnego i lokalnego przynosi korzyści w biznesie. Świadczy o tym choćby przykład sieci McDonald's, która zdecydowała się wprowadzić na większości rynków zagranicznych produkty związane $\mathrm{z}$ regionem, np. dania ryżowe w Indiach i Chinach. Pozornie jest to banalnie proste. Cała sztuka polega na zachowaniu właściwych proporcji (14.08.2018; money.pl).

Glokalizację, operując przestrzenną kategorią miejsca, można rozumieć jako „umiejscowienie” w metaforycznym i dosłownym sensie (Kuciński 2011: 31). W miarę stawania się obywatelami Europy i świata nierzadko zostajemy przypisani do małej "ojczyzny prywatnej”, ,"mniejszego nieba" (Szczepański 2002), a zatem do unikalnego miejsca na Ziemi, kształtującego osobowość (Majer 2011: 43). Z kontekstów zawartych w korpusie MoncoPL glokalizacja wyłania się jako umiejscowienie w sensie dosłownym ${ }^{31}$, np.:

Każda odwiedzona strona internetowa i czas spędzony na jej przeglądaniu, frazy wpisane $\mathrm{w}$ wyszukiwarkę, przeglądane produkty i sfinalizowane zakupy, glokalizacja - nasza codzienna aktywność w Internecie nie przepada w próżni (interia.pl 26.05.2017).

Określane leksemem glokalizacja zjawisko, podobnie jak samo słowo, „można analizować wielotorowo" (Biernacka-Ligęza 2013: 163; por.: Kuciński 2011: 31-33, Słodowa-Hełpa 2017).

Stereotypowo glokalizację utożsamia się z funkcjonowaniem transnarodowych korporacji typu McDonald's, które przystosowywały swoje globalne strategie marketingowe do lokalnej specyfiki danego regionu. Tymczasem glokalizacja odnosi się do szeroko rozumianego rozwoju regionalnego, „który - uwzględniając światowe trendy - koncentruje się

jest tylko drzewami oliwnymi, który ma tylko korzenie, a jest pozbawiony lexusa, (...) się nie rozwinie" (2001: 66).

30 „Globalna produkcja dóbr, usług, idei, wartości oraz informacji musi uwzględniać lokalne uwarunkowania w stopniu, który umożliwi akceptację wszystkich produktów wysokoprzetworzonych trafiających do odbiorców w społeczeństwach lokalnych, przyswojenie i w końcu uznanie za swoje" (Miszczak 2013: 20, por.: Wnuk-Lipiński 2004: 20).

31 Leksem umiejscowić według źródeł leksykograficznych oznacza: 1. 'wyznaczyć lub określić miejsce czegoś', 2. 'ustalić czas i miejsce, w którym coś się dzieje lub odbywa', https://sjp.pwn.pl/slowniki/umiejscowiony.html [dostęp: 27.04.2020]. 
na współdziałaniu i konkurencji wielu lokalnych systemów społecznych" (Goban-Klas 2002: 242-243). Generalizując glokalizacja w zarządzaniu przedsiębiorstwami i gospodarką, zdaniem współczesnych teoretyków, „polega na uwzględnianiu na poziomie lokalnym, lokalnych wartości lokalizacyjnych, przestrzennych i społeczno-kulturowych oraz ich umiejętnym łączeniu $\mathrm{z}$ uniwersalnymi wartościami generowanymi i transformowanymi przez globalizację" (Kuciński 2015: 13-14). Celem glokalizacji jest zatem takie „przyswajanie sobie aspektów globalizacji przez kulturę danego kraju, jakie przyczynią się do rozwoju i zróżnicowania społeczeństwa, nie przytłaczając go" (Friedman 2001: 360). Glokalizacja jest rodzajem filtra, poprzez który społeczeństwa „przepuszczają” swoje kulturowe dziedzictwo i „konfrontują z homogenizującym wpływem globalnego kapitalizmu" (Słodowa-Hełpa 2017: 13). Tak więc glokalizację postrzegać należy jako proces wytwarzania produktów lub oferowania usług dla światowych odbiorców z jednoczesnym dopasowywaniem ich do wymogów lokalnych rynków ${ }^{32}$. Mechanizm glokalizacji, w dużym uproszczeniu, można przedstawić następująco: globalność penetruje lokalność, lokalność reaguje i powstaje glokalność (Majer 2011). Przy czym - jak zauważa Andrzej Majer - „lokalność nie musi być wcale «lokalna». Z kolei globalizacja nie musi być uniwersalna, ponieważ lokalne grupy lub społeczności mogą odgrywać aktywną rolę $\mathrm{w}$ jej transformacji, nie będąc natomiast zmuszane do daleko sięgających przekształceń wzorów własnej kultury" (2011: 43) 33. Zjawisko glokalizacji przyczynia się z całą pewnością do „zmiany stosunku do dziedzictwa kulturowego małych ojczyzn i wspólnot lokalnych, do niedawna traktowanych jako przejaw pejoratywnie rozumianej ludowości, konserwatyzmu, czy wręcz zacofania" (Dyczewski 2002: 247). Kultury lokalne stwarzają możliwość zachowania różnorodności w globalizującym się świecie ${ }^{34}$. Korzystanie z kul-

32 Działania o charakterze glokalizacyjnym doskonale ilustrują zabiegi specjalistów od marketingu zatrudnionych przez globalną korporację McDonald's we Francji. W celu dostosowania do wymogów lokalnego rynku zaproponowali oni zamianę maskotki Ronalda McDonalda na Asteriksa - postać z popularnej francuskiej kreskówki (Birnacka-Ligęza 2003: 164).

33 Z obserwacji A. Majera wynika, że członkowie lokalnych kultur mogą nawet manipulować elementami napływającymi „,z zewnątrz". Kontrowersyjnym przykładem potwierdzającym tę tezę, według badacza, jest muzyka disco-polo popularna na wiejskich zabawach i dyskotekach w małych miastach (2011: 43).

34 „Tylko różnorodność, nawet pewna konfliktowość - byle otwarta, może być płodnym zaczynem do narodzin nowych wartości kulturowych" (Podgórecki 2009: 34). 
tury globalnej nie wyklucza zatem uczestnictwa w kulturze narodowej czy lokalnej. Wręcz przeciwnie - często - eksponuje je. Mamy tu więc do czynienia z dwiema przeciwnymi tendencjami: „dążeniem do globalności, ale i partykularności, lokalności" (Jewtuchowicz 2005: 44). Tendencje "prowadzące do homogeniczności i centralizacji pojawiają się równocześnie z tendencjami do heterogeniczności i decentralizacji" (Biernacka-Ligęza 2013: 164). Na tej podstawie można wyróżnić dwa (równie ważne) konteksty współczesnej glokalizacji - tzn. płaszczyznę globalną w lokalnej oraz lokalną w globalnej - związane z jej dwoma cechami: dostępnością ${ }^{35}$ i bliskością ${ }^{36}$ będącymi wynikiem postępu w nowych technikach informatycznych i komunikacyjnych wzmacniających rozwój lokalny oraz ułatwiających procesy globalne (Torrès 2004: 25).

Autorzy opracowań opisujących najnowsze zjawiska dotyczące współczesnej przedsiębiorczości glokalizację określają jako proces „tajemniczy"37; wielowymiarowy. Zgodnie podkreślają, że charakter międzydyscyplinarny procesu wyzwala „różnorodne sposoby jego interpretacji” (Biernacka-Ligęza 2013: 163). Glokalizacja „niczym Swarożyc ma (...) niby identyczne, jednak odmienne oblicza" (Kuciński 2011: 31). Pierwszym z nich jest wrastanie elementów gospodarki globalnej, czyli globalnych podmiotów gospodarczych, w lokalne struktury ekonomiczne i społeczne, powiązane z przystosowaniem globalnych produktów i ich

35 Dostępność, jak pisze Olivier Torrès, oznacza możliwość „prawie natychmiastowego połączenia rożnych punktów ziemi oddalonych od siebie nawet znaczną odległością. Jednakże połączenia te wymagają ciągłości organizacyjnej. Stąd dostępność jest ściśle związana z pojęciem sieci oraz pojęciem bliskości funkcjonalnej lub organizacyjnej" (2012: 25).

36 Bliskość jest zjawiskiem złożonym. Bliski to taki, gdzie odległość między określonym punktem w przestrzeni lub czasie a tym, o którym mowa, jest nieduża. „Blisko, pod ręką, znajduje się przede wszystkim to, co zwyczajne, swojskie i tak dobrze znane, że oczywiste; coś lub ktoś widywany i spotykany codziennie, wpisany w porządek zwykłego dnia i powszednie zajęcia. «Pobliże» to przestrzeń, wewnątrz której można się czuć u siebie, w domu; przestrzeń, w której człowiek gubi się rzadko albo zgoła nigdy; gdzie nie dochodzi do sytuacji, w których brak mu słów lub nie wie, jak się zachować" (Bauman 1997: 19). Dzięki bliskości możliwe jest wspólne podejmowanie decyzji i działań, w wyniku których terytorium "do wzięcia" przekształca się w terytorium "działające" (Jewtuchowicz 2005: 48).

37 Zob. http://www.coslychacwbiznesie.pl/biznes/co-to-jest-glokalizacja [dostęp: 30.01. 2020]. 
reklamy do wymogów (warunków) rynku lokalnego ${ }^{38}$. Drugą postać stanowi wchodzenie lokalnych gospodarek i społeczności w sieć globalnych powiązań ${ }^{39}$. Trzecia forma to funkcjonowanie lokalnych gospodarek $\mathrm{w}$ warunkach wynikających $\mathrm{z}$ globalizacji, przy wyraźnej tendencji do atomizacji i separatyzmu jednostek przestrzennych, np. w postaci megalopolii ${ }^{40}$. Kolejną "odsłoną" jest postępująca ewolucja ontologicznego znaczenia lokalności, która pod wpływem glokalizacji staje się czymś zupełnie innym. Klasyczny podział świata na centra i peryferie ulega zatarciu w wyniku procesów globalizacyjnych ${ }^{41}$. Powstają "nowe lokalności"; hybrydy ${ }^{42}$. Ostatnim obliczem glokalizacji jest czynienie globalnymi lokalnych produktów, symboli i wartości kulturowych, etycznych oraz moralnych ${ }^{43}$.

Z kontekstów zawartych w korpusie MoncoPL, glokalizacja wyłania się jako mechanizm oparty z jednej strony na myśleniu globalnym i działaniu lokalnym. Świadczą o tym następujące przykłady:

Można przywołać w tym kontekście termin glokalizacja: myślenie globalne, działanie lokalne (21.03.2019, niedziela.pl);

38 Dziś firmy globalne muszą działać lokalnie, z użyciem nie tylko lokalnego języka, ale przede wszystkim przy wykorzystaniu lokalnych kodów i wzorców kulturowych. Wystarczy porównać strony internetowe koncernu Coca-Cola z różnych stron świata. Każda ze stron jest graficznie nieco inaczej skomponowana, ale główny motyw i logo Coca-Coli pozostaje niezmienne, http://www.coslychacwbiznesie.pl/biznes/co-to-jest-glokalizacja [dostęp: 30.01.2010].

39 Za przykład może tu posłużyć ogólnoeuropejski program pod nazwą „Europejska Stolica Kultury", którego zadaniem jest z jednej strony pogłębianie integracji europejskiej, z drugiej zaś promowanie walorów kulturowych poszczególnych regionów (Synak 2003: 253).

40 Tego typu tendencje glokalizacyjne ucieleśniają takie odrębne „miasta-światy”, jak: Mexico, Manhattan czy Sao Paulo. Stają się one całymi państwami zakotwiczonymi na ograniczonym terytorium. Utrzymują jednak „związki symboliczne, rynkowe oraz finansowe z całym światem" (Torrès 2012: 26).

41 Nie jest on już tak jasny i jednoznaczny. „Określone zjawiska zachodzą w każdym miejscu na globie bez względu na długość, czy szerokość geograficzną" (Veltz 1966: 44). Por.: Eliade 1970, Handke 1993.

42 Szczególnie w miastach, gdzie imigranci i elity muszą dopasować się do siebie i pielęgnować tradycję za granicą, tworzą się kultury i tożsamości mieszane (Biernacka-Ligęza 2003: 165). Dzisiaj nie wymaga się od emigrantów asymilacji (Majer 2011: 43). Można się o tym przekonać odwiedzając chociażby Chinatown w Londynie, Brooklyn Chinatown, Flushing Chinatown czy Little Italy w Nowym Yorku.

43 Lokalność przestaje przede wszystkim być synonimem zaściankowości i wykluczenia. „W lokalnych społecznościach i w lokalnych gospodarkach narasta pod wpływem globalizacji świadomość ich specyfiki, a zarazem roli i znaczenia tej specyfiki zarówno dla lokalnych gospodarek i społeczności, jak i dla ich ponadlokalnych układów odniesienia, nie wykluczając układu globalnego" (Kuciński 2015: 32). 
O tym, jak potężnym narzędziem rozwojowym może okazać się tzw. glokalizacja, porozmawiają goście z Polski, Włoch oraz Słowenii w trakcie panelu „Myśl globalnie, działaj lokalnie - globalizacja vs. glokalizacja” (14.08.2018, innpoland.pl);

Temu problemowi poświęcona będzie dyskusja „Myśl globalnie, działaj lokalnie - globalizacja vs. glokalizacja" w ramach XXVIII Forum Ekonomicznego w Krynicy (4-6. września 2018 r.) (22.08.2018, interia.pl).

$Z$ drugiej zaś rozumiana jest jako działanie integrujące sprzeczne tendencje, to znaczy perspektywę globalizacyjną oraz regionalną, lokalną, środowiskową i grupową:

Godzenie sprzeczności to nie lada sztuka, ale potrafi przynieść wymierne korzyści. Przekonują się o tym biznesowi giganci, którzy dzięki umiejętności harmonijnego łączenia pierwiastka globalnego i lokalnego, dostosowują swoją ofertę do regionalnych rynków. Doskonale obrazuje to przykład sieci McDonald's w Indiach czy Chinach (14.08.2018, innpoland.pl) ${ }^{44}$.

Zdaniem Zygmunta Baumana glokalizacja to proces „re-stratyfikacji świata", czyli ponownego (opartego na innych niż dotąd zasadach) "uwarstwienia". Jest to proces budowania nowej samoodtwarzającej się hierarchii o ogólnoświatowym zasięgu (1997: 61), który w efekcie finalnym doprowadza do: 1. różnorodności (jako naturalnej i elementarnej właściwości życia społecznego) będącej wynikiem łączenia się elementów globalnych i lokalnych; 2. niwelowania lęku przed traumą globalizacji pojmowanej jako „spiętrzona fala zmywająca zrozumiałe różnice i wartości lokalnych kultur" (Kuciński 2015: 9); 3. wyjaśnienia pragmatycznie konfliktów i napięć jako zjawisk naturalnych, a co ważniejsze - przemijających (Majer 2001: 41).

Zaproponowane $\mathrm{w}$ niniejszym tekście rozumienie zjawiska glokalizacji wymaga uszczegółowienia. Przywoływany proces poza aspektem ekonomicznym i socjologicznym ma również charakter kulturowy a co

\footnotetext{
44 Analogiczną definicję odnajdziemy w OJUW z przykładem: Glokalizacja oznacza dla spółek międzynarodowych konieczność działania na rynku globalnym z jednoczesnym uwzględnieniem potrzeb rynku lokalnego (www.pb.pl), http://nowewyrazy.uw.edu.pl/haslo/glokaliza cja.html [dostęp: 27.04.2020].
} 
za tym idzie - językowy. O ile opracowań dotyczących tendencji globalizacyjnych ustawicznie przybywa, o tyle glokalizacja, alter ego globalizacji, mam wrażenie, pozostaje na marginesie zainteresowań badaczy współczesnych zjawisk językowo-kulturowych. A przecież powiązane ze sobą lokalny i globalny pierwiastek dzisiejszego życia społeczno-kulturowego nierozerwalnie współuczestniczą w tworzeniu naszego "tu i teraz", jak również „tam i potem”.

\section{BIBLIOGRAFIA}

Appadurai A., 2005, Nowoczesność bez granic, tłum. Z. Pucek, Kraków.

Appadurai A., 1995, The Production of Locality, w: Counterworks: Managing the Diversity of Knowledge, red. R. F. Routledge, London, s. 204-225.

Bartmiński J., 2001, Styl potoczny, w: Wspótczesny język polski, red. J. Bartmiński, Lublin, s. 115-135.

Bauman Z., 2000, Globalizacja, 2000.

Bauman Z., 1997, Glokalizacja, czyli komu globalizacja, a komu lokalizacja, „Studia Socjologiczne" 1997, nr 3, s. 53-69.

Beck U., 1986, Risikogesellschaft. Auf dem Weg in eine andere Moderne, Frankfurt.

Beck U., 2002, Macht und Gegenmacht im globalen Zeitalter. Neue weltpolitische Ökonomie, Frankfurt.

Beck U., 2004, Społeczeństwo ryzyka. W drodze do innego modernizmu, tłum. S. Cieśla, Warszawa.

Beck U., 2005, Władza i przeciwwładza w epoce globalnej. Nowa ekonomia polityki światowej, tłum. J. Łoziński, Warszawa.

Biernacka-Ligięza I., 2013, Glokalizacja - byt wyobrażony czy realna potrzeba?, w: Antynomie polityczności: artykuty, eseje i szkice dedykowane Profesor Barbarze Goli, red. K. Minkner, L. Rubisz, Opole, s. 163-170, https://repo.uni. opole.pl/docstore/download/UOb969f2107e1c40669c08e814e545926e/Bier nacka-LagiezaI-Glokalizacja.pdf [dostęp: 07.02.2019].

Buttler D., 1973, Dyskusyjne zagadnienia opisu polskich gwar środowiskowych, w: Govornite formi i slovenskite literaturni jazici, Skopije, s. 153-159.

Buttler D., 1982, Miejsce języka potocznego wśród odmian wspótczesnej polszczyzny, w: Język literacki i jego warianty, red. S. Urbańczyk, Łódź.

Buttler D., Krukowska H., Satkiewicz H., 1989, Kultura języka polskiego, Warszawa, t. 1.

Czainska K., 2010, Odkryć zarządzanie, Warszawa.

Dąbrowska A., 2000, Sampling, vanselling, merchandising. O stownictwie pracowników marketingu, w: Słownictwo współczesnej polszczyzny w okresie przemian, red. J. Mazur, Lublin, s. 131-140. 
Dyczewski L., 2002, Trwałość i zmienność kultury polskiej, Lublin.

Eliade M., 1970, Sacrum, mit, historia, przeł. A. Tatarkiewicz, Warszawa.

Friedman T. L., 2001, Lexus i drzewo oliwne. Zrozumieć globalizacię, tłum. T. Hornowski, Poznań.

Furdal A., 1973, Klasyfikacja odmian współczesnego języka polskiego, Wrocław.

Geddes P., 1915, Cities in Evolution: An Introduction to the Town Planning Movement and to the Study of Civics. Williams and Norgate: London, https://www.ncbi. nlm.nih.gov/pmc/articles/PMC4557557/ [dostęp: 07.02.2019].

Goban-Klas T., 2002, Glokalizacja jako remedium na globalizację, w: Oblicza procesów globalizacji, red. M. Pietraś, Lublin.

Grabias S., 1970, Kontaminacje we współczesnym języku polskim. Próba charakterystyki, Annales Universitatis Mariae Curie-Skłodowska Lublin - Polonia, Vol. XXV, 6, s. 118-145, http://bazhum.muzhp.pl/media// files/Annales_Universitatis _Mariae_Curie_Sklodowska_Sectio_F_Nauki_Filozoficzne_i_Humanistyczne/ Annales_Universitatis_Mariae_Curie_Sklodowska_Sectio_F_Nauki_Filozoficz ne_i_Humanistyczne-r1970-t25 / Annales_Universitatis_Mariae_Curie_Sklodo wska_Sectio_F_Nauki_Filozoficzne_i_Humanistyczne-r1970-t25-s117145/An nales_Universitatis_Mariae_CurieSklodowska_Sectio_F_Nauki_Filozoficzne_i Humanistyczne-r1970-t25-s117-145.pdf [dostęp: 28.02.2020].

Guziejewska, B., 2008, Glokalizacja - oksymoron czy wyzwanie dla samorządu terytorialnego?, "Samorząd Terytorialny”, nr 7-8, s. 5-14.

Handke K., Pojęcie "region" a symbolika "środka”, w: Region, regionalizm - pojęcia i rzeczywistość, red. K. Handke, Warszawa, s. 105-121.

Jewtuchowicz A., 2005,Globalne uwarunkowania rozwoju lokalnego - rozważania na temat glokalizacji, „Acta Universitatis Lodziensis. Folia Oeconomica”, nr 186, Łódź, http://cejsh.icm.edu.pl/cejsh/element/bwmeta1.element.hdl_11089_ 18021/c/foe186_Aleksandra_Jewtuchowicz_33_49.pdf [dostęp: 07.02.2019].

Jewtuchowicz A., 2005, Terytorium i wspótczesne dylematy jego rozwoju, Łódź.

James H., 2010, The End of Globalization, Cambridge.

Kempny M., 1988-2002, Globalizacja, w: Encyklopedia socjologii, t. 1, Warszawa.

Klemensiewicz Z., 1953, O różnych odmianach współczesnej polszczyzny, Warszawa, s. $38-43$.

Konopka D., 2015, Glokalizacja zaufania publicznego jako nowa kategoria socjoeko-nomiczna, „Kwartalnik Nauk o Przedsiębiorstwie”, nr 3, s. 20-29.

Kosmala A. [rec.], Ulrich Beck, Władza i przeciwwładza w epoce globalnej. Nowa ekonomia polityki światowej, tłum. J. Łoziński, Warszawa 2005, ss. 412, https://repozytorium.amu.edu.pl/bitstream/10593/6852/1/17_Przegl_d\%2 0pi_miennictwa_Anita_Kosmala_206-207.pdf [dostęp: 28.01.2020].

Kuciński K., 2015, Glokalizacja a zarządzanie, „Kwartalnik Nauk o Przedsiębiorstwie" nr 3, s. 12-14, https://docplayer.pl/41718605-Glokalizacja-a-zarzadza nie.html [dostęp: 07.02.2019]. 
Kuciński K., 2011, Glokalizacja jako indygenizacja globalizacji, „Rocznik Żyrardowski", t. 9, s. 15-39, http://mazowsze.hist.pl/29/Rocznik_Zyrardowski/891/ 2011/34196/ [dostęp: 07.02.2019].

Kuć J., 2011, Nowe profesjolektalne słownictwo polskie (na przykładzie języka zawodowego menadżerów i trenerów), w: Vidy jazyka a jazykovedy. Venovanú životnému jubileu doc. PhDr. Miloslavy Sokolovej, red. M. Ološtiak, M. Ivanová, D. Slančová, Prešov, s. 348-360.

Lukszyn J. (red.), 2005, Języki specjalistyczne. Słownik terminologii przedmiotowej, Warszawa.

Majer A., 2011, Lokalność w cieniu globalizacji, "Annales Universitatis Mariae Curie-Skłodowska", Lublin - Polonia vol. XXXVI, 2 sectio I, s. 27-46, http:// dlibra.umcs.lublin.pl/Content/23700/czas16080_36_2_20112.pdf [dostęp: 07.02. 2019].

Miszczak K., 2013, Procesy glokalizacji w rozwoju nowoczesnego terytorium, "Acta Universitatis Lodziensis, Folia Oeconomica", nr 289, s. 19-32.

Nelson D. (red.), 1989, The Penguin Dictionary of Mathematics, London.

Otrębski J., 1948, Życie wyrazów w języku polskim, Poznań.

Pałka P., Kwaśnicka-Janowicz A., 2017, Przewodnik po zasobach internetowych, Seria: Biblioteczka Towarzystwa Miłośników Języka Polskiego nr 28, Kraków.

Pasmonik B., 2013, Globalizacja kultury czy glokalizacja kultur, w: Krótkie wykłady z socjologii: kategorie, problemy, subdyscypliny, red. A. Firkowska-Mankiewicz, T. Kanash, E. Tarkowska, t. 2, Warszawa, s. 118-138.

Piekot T., 2008, Jezyk w grupie społecznej. Wprowadzenie do analizy socjolektu, Wałbrzych.

Pisarek W., 2006, Słownik terminologii medialnej, Kraków.

Podedworna H., 1999, Analiza struktur społecznych. Wybrane przykłady, Warszawa.

Podgórecki J., 2009, Globalizacja a tożsamość człowieka, w: Globalizacja - naród - jednostka. Zagadnienia tożsamości kulturowej, red. T. Kuczur, A. Błachnio, Torun, s. $100-113$.

Rzepka A., 2014, Globalizacja w teorii i praktyce (e-Book).

Skubalanka T., 1976, Założenia analizy stylistycznej, w: Problemy metodologiczne wspótczesnego literaturoznawstwa, red. H. Markiewicz, J. Sławiński, Kraków, s. 250-273.

Słodowa-Hełpa M., 2017, Między globalizacja a glokalizacją, „Studia Oeconimica Posnaniensa" vol. 5, no. 5, http://soep.ue.poznan.pl/New_SOEP_site/jdown loads/Wszystkie\%20numery/Rok\%202017/01_slodowa_helpa.pdf [dostęp: 07.02.2019].

Smółkowa T., 2001, Nowe słownictwo polskie, w: Współczesny język polski, red. J. Bartmiński, Lublin, s. 397-441. 
Strawińska A., 2018a, Uwagi o kondycji dwudziestopierwszowiecznej polszczyzny z perspektywy procesów globalizacyjnych, „Roczniki Humanistyczne”, t. LXVI, z. 6, s. 197-215.

Strawińska A., 2018b, Wpływ globalizacji i nowych technologii na zachowania językowe wspótczesnych Polaków, „Pogranicze. Studia Społeczne”, t. XXXII: Sytuacja jezzykowa świata w okresie globalizacji, s. 145-165.

Szczepański M. S., 2002, Społeczności lokalne i regionalne a ład kontynentalny i globalny, Kraków.

Szopa B., Ślęzak E., 2018, Społeczne aspekty globalizacji, Warszawa.

Synak B., 2003, Małe ojczyzny w globalnej wiosce, w: Globalizacja i my. Tożsamość lokalna wobec trendów globalnych, red. R. Piekarski, M. Graban, Kraków, s. 244-298.

Torrès O., 2012, Lokalna globalizacja czy globalna lokalizacja: Rozważania na temat glokalizacji, „Acta Universitatis Lodziensis, Folia Oeconomica”: Terytorialny wymiar procesów innowacji i przedsiębiorczości: studia polsko-francuskie, nr 212/275.

Urbańczyk S., 1956, Rozwój języka narodowego, [w:] Z dziejów powstania języków narodowych i literackich, red. Z. Stieber, Warszawa s. 23-26.

Więckiewicz-Archacka M., 2014, Glokalizacja a media oddolne: lokalne społeczności w globalnej sieci, „Zeszyty Naukowe Ostrołęckiego Towarzystwa Naukowego", nr 28, s. 314-325, http://mazowsze.hist.pl/28/Zeszyty_Naukowe_ OstroleckiegoTowarzystwa_Naukowego/1030/2014/37135/ [dostęp: 07.02. 2019].

Wierżyński W., 2015, Wady i zalety stosowania crowdsourcingu, [w:] Tłum jako zródto wiedzy i kapitału, red. A. Boniewicz i in., Warszawa, s. 30-36.

Wilkoń A., 2003, Gatunki mówione, Katowice.

Wosińska W., 2007, Oblicza globalizacji, Sopot.

Wnuk-Lipiński E., 2004, Oblicza globalizacji - konceptualizacja pojęcia, w: Globalizacja $i$ co dalej?, red. S. Amsterdamski, Warszawa, s. 15-30.

Veltz P., 1966, 1996, Mondialisation, villes et terriioires. L'économie d'Archipel, Paris.

\title{
GLOCALISATION. AN ATTEMPT AT CULTURAL DEFINITION
}

\begin{abstract}
The aim of presented article is to introduce the phenomenon of glocalisation, insufficiently studied, at least in Polish linguistics. This phenomenon belongs to the latest processes of modern entrepreneurship. Glocalisation has been shifted from economic to social studies. Works in the field of economics and broadly defined trade bring a thorough analysis of this issue. The author of this article attempts to systematise the understanding of glocalisation, as
\end{abstract}


developed by scholars representing, apart from linguistics, such fields as: sociology, political science, and cultural anthropology. Including the works of scholars in a variety of disciplines is necessary in this case, due to the special features of the term glocalisation. It is representative of the latest professional vocabulary that has reached the Polish Language with a wave of borrowings associated with the globalisation processes. Some researchers treat glocalisation symbolically as the reverse of globalisation; glocalisation $=$ globalisation + local . Nowadays, linguists increasingly frequently have to refer to the experiences and achievements of scholars from often very distant, seemingly disconnected, fields when describing new varieties of language and new phenomena. This type of extensive cooperation eventually allows achieving a broad research perspective, which is so often postulated in modern science.

Key words: glocalisation, globalisation, public relations, modern Polish vocabulary, localism, contemporary global marketing 